Fournal of Medical Genetics (1971). 8, 136.

\title{
The Genetic Basis of Variation in Factor 8 Levels Among Haemophiliacs
}

\author{
D. F. ROBERTS
}

\section{From the Laboratory of Human Genetics, University of Newcastle upon Tyne}

The recent identification.by Denson et al (1969) of two distinct types of haemophilia $\mathbf{A}\left(\mathbf{A}^{+}\right.$and $\left.\mathbf{A}^{-}\right)$recalls the early explanation, of the variation in severity observed in haemophilia cases, by Haldane (1935) who noted it is likely that several allelomorphs of haemophilia exist'. This hypothesis, though it has not been strictly scrutinized, has influenced thinking on factor 8 levels both in normal and affected subjects.

The hypothesis was extended by Graham, McLendon, and Brinkhous (1953) and Brinkhous et al (1954) to cover the wide range of variation of factor 8 levels observed in normal persons. They postulated a series of alleles located on the $\mathrm{X}$ chromosome, and haemophilia appeared in the distribution as a threshold effect due to the presence of an abnormal gene occurring at the same locus as the normal allelic series. Their hypothesis was soon shown to be untenable. Pitney and Arnold (1959) argued that it implied different values in normal males and females and similar values in normal males and carrier females, which arose from a dosage effect, whereas the converse was indeed observed. This rebuttal became less convincing with the elucidation of dosage compensation, the Lyon effect, and in particular the analogous behaviour of G6PD levels in deficient males, heterozygous females, and normals, the gene for G6PD deficiency being situated at an X-locus close to that for the classical haemophilia gene. But the hypothesis of an X-linked allelic series was convincingly disposed of by Kerr's data (1965) on normal individuals. In particular he obtained similar correlations for father/son and mother/son pairs, whereas with an X chromosome series these should differ widely; secondly he observed no bimodality of factor 8 distribution among normal brothers, whereas this would be expected from the segregation of the maternal X chromosomes.

Graham (1959) modified the concept of a series of

Received 17 July 1970.
$\mathrm{X}$-borne alleles, and suggested control of factor 8 levels at an X-linked and at least one autosomal locus, so that there are at least two separate loci concerned in the synthesis which takes place in two or more stages. This suggestion has been amplified in theoretical models, in a series of papers (eg, Graham, Barrow, and Roberts, 1965), based on current views on protein synthesis. The most recent proposes that factor 8 is a polymer formed of at least two polypeptide chains, one of which is controlled by a structural gene on the $\mathrm{X}$ chromosome and the other by a pair of structural genes on homologous autosomes. Mutation at the $\mathrm{X}$ chromosome locus results in factor 8 deficiency (haemophilia) and at the autosomal locus in von Willebrandt's disease. Dreyfus (1969) suggested that it is an inducer of the synthesis of factor 8 that is missing and produces the disturbance of coagulation in von Willebrandt's disease. Though these models are illuminating they are of course simplified. It seems rather unlikely that the genetical control of normal factor 8 level is through a few major genes which influence the rate of synthesis of the factor, and it appears necessary to seek multigenic control.

Pitney and Arnold (1959) suggested that the similar distributions observed in normal males and females could be explained on the hypothesis that plasma AHF concentration in normals is under the control of autosomal genes, and indeed the discovery of autosomal mutations that influence the factor level confirms some autosomal effect. But, they pointed out, the situation of the classical haemophilia gene on the $\mathrm{X}$ chromosome implies that it either interferes with the expression of the autosomal genes or is itself responsible for a substance which inhibits or destroys plasma AHF. Further evidence comes from studies of factor 8 levels in members of normal families (Pitney et al, 1962; Kerr et al, 1965 and 1966) making due allowance for known sources of nongenetic variability. Both studies are in close agreement on a number of points. Variation between husband and 
wife in the level of factor 8 is similar to variation between parents from different families. Both parents make approximately equal contributions to the levels in their children. Variation is less among sibs than between children from different families. When the parental effect is removed variation between sibships remains significant. There is a highly significant regression of child on midparent value. The product-moment correlation coefficients in normal families in Kerr's study are all positive and moderately high. These observations together suggest the influence of a series of autosomal genes. But Kerr's correlation coefficients are consistently lower than those expected on an additive autosomal gene hypothesis; however, of the 9 quoted between relatives of different types, 3 are within 2 standard errors, 4 within 1 standard error, and 2 within half a standard error of the expected values. Unfortunately a low positive correlation coefficient was observed between parents, some $1 \frac{1}{2}$ times its standard error. If this is ignored and regarded as not significantly different from zero, the correlation coefficients are compatible with autosomal additive genetic interpretation and relatively high heritability; if however the interparental correlation is regarded as meaningful then the correlation coefficients are appreciably reduced and suggest a much greater environmental contribution. A second line of evidence came from a small series of normal twins, showing a slightly but not significantly higher intraclass correlation coefficient for monozygotic $(0.92)$ than for dizygotic $(0.87)$ pairs. Further evidence came from families with factor 8 deficiency, the diminution in the mean level in genetically proven heterozygotes as compared with that for normals from unaffected and affected families being highly significant. The frequency distribution of levels in normals was smooth and showed no consistent segregation, approaching a normal curve in Kerr's series and a skewed curve in Pitney's. All these findings suggest that genetical control in normals is complex, and involves a number of pairs of autosomal alleles with a cumulative effect on resulting factor 8 concentration, interacting with at least one $\mathrm{X}$ locus and with environment.

Haemophiliacs too differ in AHF level, which may vary from zero to some $30 \%$ of normal. Does this variability represent a series of alleles, as suggested by Haldane; does it represent environmental influence on the expression of a single allele; or does it represent contributions of autosomal loci? These suggestions are easy to test. If autosomal loci contributed to this variation, one would expect that by comparison with an affected propositus, the remoter the degree of an affected male relative and hence the fewer autosomal genes shared in common, the less the similarity between factor 8 levels as measured by product-moment correlation coefficients. If environment contributed appreciably then correlation coefficients would be low.

\section{Material and Results}

Data for affected males in haemophilia A families are available from the classic series of studies carried out in Sweden. These data include the AHF level as a percentage of normal, the B factor as a percentage of normal, coagulation time in minutes, prothrombin consumption residual (\%), prothrombin plus factor $7(\%)$, factor 5 (\% of normal) and fibrinogen $(\mathrm{g} / 100 \mathrm{ml})$. These data are from Nilsson, Blömback, and Ramgren (1961) and the later data of the same authors with Ahlberg (Nilsson et al, 1965), and were interpreted with the assistance of the pedigree diagrams in Ramgren, Nilsson, and Blömback (1962) and Ahlberg (1965). These data could be tabulated for pairs of relatives of different coefficients of relationship, though since not all results were available for each individual the number of pairs was not constant for all variables. For each set of relatives of a given degree the correlation coefficients were calculated for each of these variables. The results are set out in Table I.

For the closest degree of relationship examined, pairs of brothers, there is no significant correlation in levels of the B factor, or of prothrombin + factor 7, and this is to be expected where the range of interfamilial variation is relatively slight by comparison with intrafamilial and technical error. Moderate levels of the brother/brother correlation coefficient (about 0.5), both significant, emerged for prothrombin and factor 5 level. Highly significant, high correlations, appear for AHF, coagulation time, and fibrinogen amount. No significant correlations of the B factor level or the prothrombin and factor 7 levels emerge for other degrees of relationship, nor are they significant for the prothrombin and factor 5 levels. This may be in part due to the very small number of pairs of the three remoter degrees of relationship. Despite the high correlation of fibrinogen levels in brothers, it is not significant in any other degree of relationship. But the two variables of outstanding interest are the coagulation time and the AHF level. For the AHF levels, all correlation coefficients are high and significant; there is no diminution in the correlation coefficient in the more remote degrees of relationship, and indeed they are all remarkably similar. As might be expected if coagulation time were a direct reflection of the AHF level, the correlation coefficients of coagulation time also show little variation with degree of relationship, 
TABLE I

CORRELATION COEFFICIENTS BETWEEN AFFECTED RELATIVES

\begin{tabular}{|c|c|c|c|c|c|c|}
\hline \multirow[b]{2}{*}{ Variables } & \multicolumn{6}{|c|}{ Coefficient of Relationship } \\
\hline & $\begin{array}{l}0.5 \\
\text { (brothers) }\end{array}$ & $\begin{array}{l}\frac{1}{4} \\
\text { (uncle/nephew, } \\
\text { grandfather } / \\
\text { grandson) }\end{array}$ & $\begin{array}{c}\frac{1}{8} \\
\text { (1st cousin, } \\
\frac{1}{2} \text { uncle/nephew, } \\
\text { great uncle! } \\
\text { gt. nephew }\end{array}$ & $\begin{array}{l}\text { (1st cousin once } \\
\text { removed, } \\
\frac{1}{2} \text { first cousin) }\end{array}$ & $\begin{array}{l}\text { (2nd cousin, } \\
\text { 1st cousin twice } \\
\text { removed } \\
\frac{1}{2} \text { cousin once } \\
\text { removed) }\end{array}$ & $\begin{array}{l}\text { (2nd cousin once } \\
\text { removed) }\end{array}$ \\
\hline $\begin{array}{l}\text { AHF } \\
\text { B Factor } \\
\text { Coagulation time } \\
\text { Prothrombin } \\
\text { Prothrombin and factor } 7 \\
\text { Factor } 5 \\
\text { Fibrinogen }\end{array}$ & $\begin{array}{l}0.913^{*} \\
\text { NS } \\
0.854^{*} \\
0.538 \ddagger \\
\text { NS } \\
0.592^{*} \\
0.790^{*}\end{array}$ & $\begin{array}{l}0.930^{*} \\
\text { NS } \\
0.614 \ddagger \\
\text { NS } \\
\text { NS } \\
\text { NS } \\
\text { NS }\end{array}$ & $\begin{array}{l}0.959 * \\
\text { NS } \\
0.834 t \\
\text { NS } \\
\text { NS } \\
\text { NS } \\
\text { NS }\end{array}$ & $\begin{array}{l}0.975^{*} \\
\text { NS } \\
0.772 \ddagger \\
\text { NS } \\
\text { NS } \\
\text { NS } \\
\text { NS }\end{array}$ & $\begin{array}{l}0.721 t \\
\text { NS } \\
0 \cdot 892 t \\
\text { NS } \\
\text { NS } \\
\text { NS } \\
\text { NS }\end{array}$ & $\begin{array}{l}0.903 t \\
\text { NS } \\
0.994 t \\
\text { NS } \\
\text { NS } \\
\text { NS } \\
\text { NS }\end{array}$ \\
\hline Maximum number of pairs & 41 & 22 & 19 & 16 & 16 & 7 \\
\hline
\end{tabular}

NS = Not significant.

* Significant at 0.001.

+ Significant at 0.01 .

$¥$ Significant at 0.05 .

though there is rather more variation about the common level.

The high correlation coefficients of AHF level suggest that there is little in the way of environmental influence on this variable. The fact that there is no diminution in correlation coefficient in the more remote degrees of relationship, suggests that there is little or no contribution of autosomal loci to AHF level in haemophiliacs. The different AHF levels found in these patients therefore is more reasonably attributed to a series of alleles, each allele being specific to the particular family in which it occurs and effectively inhibiting the action of the series of autosomal alleles governing factor 8 variation in normal individuals.

These correlations for AHF level are sufficiently high to allow the level to be estimated in a patient from a known level in an affected relative. The regression equations for predicting AHF level from that of a first or second degree affected relative are set out in Table II. The correlation coefficients for the other variables imply too great variation about the regression line for estimates of practical applicability to be made.

A similar analysis, of the more limited data, on factor levels in affected males in haemophilia B

\section{TABLE II}

REGRESSION EQUATIONS OF AHF LEVELS IN AFFECTED CLOSE RELATIVES

\begin{tabular}{l|l}
\hline \multicolumn{1}{c|}{ Relationship } & Regression equation \\
\hline $\begin{array}{l}\text { First degree (brothers) } \\
\begin{array}{l}\text { Second degree (uncle/nephew, grandfather/ } \\
\text { grandson) }\end{array}\end{array}$ & $y=0.661+0.968 x$ \\
\hline
\end{tabular}

$\mathbf{x}$ is the AHF level expressed as a percentage of normal. families was undertaken from the same sources. Here the correlation of factor 8 level in brother pairs was not significant since there were only 15 pairs available, though at 0.46 it approached the expected value of 0.5 . The factor 9 level correlation coefficient however was highly significant in brothers, second degree and third degree pairs, despite their small numbers, and remained at a high level (respectively $0.82,0.83$, and 0.97 ). Though these data are not sufficient for regression estimates of practical applicability to be made, they suggest a similar interpretation to that proposed for the variation in factor 8 levels in haemophilia $\mathrm{A}$, an allelic series whose effects are very little modified by autosomal influence. Again it is of interest that Denson, Biggs, and Mannucci (1968) have identified two types of haemophilia $\mathrm{B}\left(\mathrm{B}^{+}\right.$and $\left.\mathrm{B}^{-}\right)$.

Thus the analysis of correlations of factor 8 level in affected relatives with haemophilia $A$ is paralleled by the limited findings regarding factor 9 levels in the few affected members of families with haemophilia B. Together they lend strong support to the conclusion of Denson et al (1969) that: 'It thus seems likely that there may be a broader spectrum of structurally defective proteins in haemophilia $A$ and $B$ and that the inheritance of the defective protein may be far more complex than was originally thought.' Indeed it may well be that the duality they observe is merely the first step in the elucidation of a more complex heterogeneity, suggested by the present analysis. (Further heterogeneity has now been demonstrated by Bennett and Huehns [1970].)

\section{Summary}

Haldane's suggestion that several allelomorphs of haemophilia exist is tested by examination of cor- 
relation coefficients of factor 8 level between affected relatives. The results suggest that there is little or no contribution of autosomal loci to AHF level in haemophiliacs. A series of alleles seems the more likely explanation of the differences in factor level.

Acknowledgement is gratefully made to $\operatorname{Dr} A$. R. Boon and $\mathrm{Dr}$ C. B. Kerr for their helpful discussions, and to Mrs Marjorie Smith for her assistance with the computations.

\section{REFERENCES}

Ahlberg, A. (1965). Haemophilia in Sweden. VII. Incidence, treatment and prophylaxis of arthropathy and other musculoskeletal manifestations of haemophilia A and B. Acta Orthopaedica Scandinavica. Suppl. No. 77.

Bennett, E., and Huehns, E. R. (1970). Using an immunological assay technique. Lancet, 2, 956-958.

Brinkhous, K. M., Langdell, R. D., Penick, G. D., Graham, J. B. and Wagner, R. H. (1954). Newer approaches to the study of hemophilia and hemophilioid states. Fournal of the American Medical Association, 154, 481-486.

Denson, K. W. E., Biggs, R., Haddon, M. E., Borrett, R., and Cobb, K. (1969). Two types of haemophilia $\left(A^{+}\right.$and $\left.A^{-}\right): A$ study of 48 cases. British fournal of Haematology, 17, 163-171.

Denson, K. W. E., Biggs, R., and Mannucci, P. M. (1968). An investigation of three patients with Christmas disease due to an abnormal type of Factor ix. Fournal of Clinical Pathology, 21, 160-165.

Dreyfus, J. C. (1969). The application of bacterial genetics to the study of human genetic abnormalities. Progress in Medical Genetics, 6, 169-200.
Graham, J. B., McLendon, W. W., and Brinkhous, K. M. (1953). Mild haemophilia: an allelic form of the disease. American fournal of the Medical Sciences, 225, 46-53.

Graham, J. B., Barrow, E. M., and Roberts, H. R. (1965). Possible implications of the autosomal and X-linked haemophilia phenotypes. In Genetics and the Interaction of Blood Clotting Factors, ed. R. B. Hunter, I. S. Wright, F. Koller, and F. Streuli. Thrombosis et Diathesis Haemorrhagica, Suppl. 17. pp. 151-161. Schattauer, Stuttgart.

Haldane, J. B. S. (1935). The rate of spontaneous mutation of a human gene. Fournal of Genetics, 31, 317-26.

Kerr, C. B. (1965). Genetics of human blood coagulation. Fournal of Medical Genetics, 2, 254-303.

Kerr, C. B., Preston, A. E., Barr, A., and Biggs, R. (1965). Inheritance of Factor VIII. In Genetics and the Interaction of Blood Clotting Factors, ed. R. B. Hunter, I. S. Wright, F. Koller, and F. Streuli. Thrombosis et Diathesis Haemorrhagica, Suppl. 17, pp. 173-179. Schattauer, Stuttgart.

Kerr, C. B., Preston, A. E., Barr, A., and Biggs, R. (1966). Further studies on the inheritance of factor VIII. British fournal of Haematology, 12, 212-233.

Nilsson, I. M., Blombäck, M., and Ramgren, O. (1961). Haemophilia in Sweden. I. Coagulation studies. Acta Medica Scandinavica, 170, 665-682.

Nilsson, I. M., Ramgren, O., Blombäck, M., and Ahlberg, A. (1965). Addendum to the review of haemophilia in Sweden 1962. Acta Orthopaedica Scandinavica. Suppl. 77, 99-132.

Pitney, W. R. and Arnold, B. J. (1959). Plasma antihaemophilic factor (AHF) concentrations in families of patients with haemorrhagic states. British fournal of Haematology, 5, 184-193.

Pitney, W. R., Kirk, R. L., Arnold, B. J., and Stenhouse, N. S. (1962). Plasma anti-haemophilic factor (Factor VIII) concentrations in normal families. British fournal of Haematology, 8, 421428.

Ramgren, O., Nilsson, I. M., and Blombäck, M. (1962). Haemophilia in Sweden. IV. Hereditary investigations. Acta Medica Scandinavica, 171, 759-769. 